\title{
VOLUNTARY \& MANDATORY TRANSFER DISCLOSURES OF FOOTBALL TEAMS AND BEHAVIOUR OF STOCK RETURNS: AN EVENT STUDY
}

\author{
Burak Babacan* \\ Gökhan Özer
}

\begin{abstract}
We use the event study methodology to examine the stock returns' consequences of voluntary and mandatory transfer disclosures of football teams. We analyzed the effects of voluntary disclosures by using the announcement of intent to enter into negotiations on transfer. On the other hand, to announce signing a contract is considered as a mandatory disclosure because the local regulations obliged football teams to announce the transfers of football players. The results of the study show that stock returns have parallel pattern regarding the voluntary and mandatory disclosures. However stock returns reaction to voluntary disclosures is statistically significant where this proposition is not valid for the mandatory disclosures. The findings of study provide evidence for the theory proposing that stock returns react to voluntary disclosures when the mandatory disclosures are less informative.
\end{abstract}

Keywords: Voluntary disclosures, mandatory disclosures, stock returns, football teams, event study.

JEL classifications: G12, G14, L11

\section{INTRODUCTION}

In accordance with the Communiqué VIII/54 of Capital Markets Board of Turkey (SPK,2009), football teams must announce their football player transfers to public via Public Disclosure Platform (PDP). However, Communiqué VIII/54 does not include a regulation for the timing of transfer announcements. Football teams often announce that they enter into

\footnotetext{
*Assistant Manager, KPMG, Turkey. Email: bbabacan@kpmg.com

** Professor, Gebze Technical University, Turkey. Email: gokozerhan@gmail.com
} 
negotiations with football players. Announcements of negotiations require a second disclosure which states whether contract is signed or cancelled. In some cases, football teams prefer only to announce the contract conclusion without any pre-disclosure about the negotiations. At this point, we noticed that there are two types of announcements that football teams make; 1) Entering into negotiations 2) Signing a contract. Announcement of signing a contract is a mandatory disclosure while announcement of entering into negotiations is a voluntary disclosure.

The major question is that why football teams voluntarily disclose their negotiations with football players? 1) Mass media releases information about all the stages of transfers 2) Both true and false news is quite dominant in mass media. This structure increases the need for adequate, accurate and punctual information for investors.

This paper analyzes the impact of voluntary disclosures on stock returns when football teams delay the delivery of accurate information to investors. Since football players are basic indicators for the success of the team, football teams may favor more voluntary disclosures to inform investors on time and avoid from false news. We used the event study methodology in order to research the impact of voluntary \& mandatory transfer announcements on stock returns. We examined the announcements that are made on Public Disclosure Platform by four Turkish football teams listed on the Borsa İstanbul (Istanbul Stock Exchange Market). We found that the impact of negotiation announcements is much stronger than the announcements of signing a contract.

The rest of the paper is arranged as follows; Section 2 reviews the literature related to the impact of voluntary disclosure on stock returns. Section 3 presents research questions of current study. The method of study is explained in Section 4. The results are presented in Section 5, and finally, summary and conclusion are discussed in section 6.

\section{LITERATURE REVIEW}

KPMG publication on the Integrated Reporting (KMPG, 2012) focuses on the gap between the information reported by companies and the information that is necessary for investors in order to assess business prospects and value. This gap causes a valuation problem which implies that the executives of companies and investors have quite different perspective 
about the value of the company shares. Mandatory disclosures such earnings might be inadequate to fill this gap while voluntary disclosures can provide better results.

There is a wide range of theoretical and empirical studies which examine the impact of voluntary disclosures on the stock returns and valuation. Early studies focused on managers' earning forecasts. Patell (1976), Waymire (1984), Ajinkya and Gift (1984) showed that voluntary disclosures of earning forecasts have information content which means that forecasts of managers have significant impact on stock returns. Pownall and Waymire (1989) examined the stock price reactions to voluntary and mandatory disclosures and found that management forecasts lead a larger stock price effect than mandatory disclosures.

There is a consensus that stock returns react to the earnings. Özer (1996) examined this relation for the firms listed on the Istanbul Stock Exchange Market and found consistent results with literature. On the other hand, there are certain conditions such as reporting losses or operating in high tech industry that make earnings less informative for the investors (Chen et al., 2002; Graham et al., 2005). Chen et al. (2002) found that managers voluntarily disclose balance sheet when their earnings are less informative.

Dedman et al. (2008) examined the UK biotechnology/ pharmaceutical sector. Accounting standards for UK biotechnology/ pharmaceutical sector obligates firms for most of research and development investments to be recognized as an expense. Therefore, UK accounting standards leads lower reported earnings for the firms investing on research and development. Dedman et al. (2008) proved that voluntary disclosures related to product development have significant impact on the share prices. Dedman et al. (2008) also proved that development announcements have much stronger impact on share prices than annual earning disclosures.

Several studies examined the impact of voluntary disclosures in terms of transparency and asymmetric information problem. Voluntary disclosure indexes are used to indicate voluntary disclosure and transparency levels, and relation between the voluntary disclosure level and stock performance examined. Healy et al. (1999) proved that improvement on disclosure level leads the higher stock valuation.

Asymmetric information is the key concept which explains why higher disclosure level leads the better valuation of firm shares. Healy and Palepu (1993) addressed to conditions that 
are creating distortions in financial reports and leading misevaluation: 1) conflict of interest between the managers and investors, 2) information advantage of managers related to investors 3) lack of regulations and audit. It is well known by economists that these factors cause the asymmetric information problem.

The outcome of asymmetric information problem about the market price is firstly documented by Akerlof (1970). Akerlof's (1970) proposition for automobile market possessing quality uncertainty can be generalized for the stock exchange markets as follow; "Owner of the good stock cannot receive the true value of his shares and he cannot even obtain the expected value of a new shares". Akerlof's (1970) proposition clearly states that misevaluation of firms is one of the outcomes of asymmetric information problem. Diamond and Verrecchia (1991) proposed that voluntary disclosure reduces asymmetric information and lead increment on the stock price. Healy and Palepu (1993) suggest expanding voluntary disclosures for the perfect communication between the managers and investors.

Current literature concludes that voluntary disclosures reduce asymmetric information and effect stock returns. However, these studies widely use the earning forecasts or transparency levels of business report to review voluntary disclosures. This paper uses an unique variable as a proxy of voluntary disclosures and provide benchmark among disclosures which can be classified as a voluntary and mandatory. Moreover results provide evidence regarding the interaction between voluntary disclosures, asymmetric information and stock returns, because football teams are subject to asymmetric information problem arising from false or unofficial news that are produced by mass media.

\section{HYPOTHESES}

Unequal access to information may lead to the misevaluation of firms. Two major characteristics of the Turkish football industry lead to unequal information processing. First, generally, arrival of new transfer information occurs before the official announcement of football teams. In this situation, mass media generally releases the information before the contract date, when finalization of transfer is not obvious but probable. Second, false news has a wide coverage in mass media. Football teams deny false news on their official web sites to deal with unequal information processing. Another option to prevent information pollution is to inform investors about the potential transfers at the exact date when the probability of transfer first occurs. This paper concerns the effect of voluntarily negotiation announcements 
on stock returns. Since the transfer news change investors' beliefs about the future performance of football teams, announcements of negotiations have the information content. We expect from these changes in the beliefs to lead larger stock returns. On the other hand, since the announcement of signing a contract is delayed information because mass media first release the information about transfer, we expect mandatory contract signing disclosures have no effect on stock returns. All these assumptions are hypothesized as follows;

$\mathrm{H}_{1}$ : Announcements of negotiations made with football players have significant impact on stock returns.

$\mathrm{H}_{2}$ : Announcements of signing a contract have no impact on stock returns.

\section{METHODOLOGY}

The event study methodology is used to prove the hypotheses of the current study. The discussion of event study methodology can be found in Strong (1992), Mackinlay (1997), Binder (1998), Corrado (2011) and Kolari and Pynnonen (2011). According to Strong (1992), there are three steps in conducting event study 1) Identifying the event dates 2) Specifying a benchmark model and calculating abnormal returns 3) Statistical tests. Parallel to these steps, we identified the exact dates of announcements of football player transfers in 2010 January and 2012 September. The announcement data have been obtained from the Public Disclosure Platform. The original sample includes 231 transfer announcement displayed on the Public Disclosure Platform. To perform event study methodology, we specified the Market Model to define abnormal returns since The Market Model is widely used model in the event studies moreover it provides smaller variance and correlations across the abnormal returns (Strong, 1992). The abnormal returns are calculated according to the model presented below, where in this model, $R_{m t}$ is the market return on the day $t$ and $R_{i t}$ is the return of stock $i$ on the day $t$ and finally $\varepsilon_{i t}$ is the abnormal return of stock $i$ on the day $t$.

$$
\mathrm{R}_{\mathrm{it}}=\alpha_{\mathrm{i}}+\beta_{\mathrm{i}} \mathrm{R}_{\mathrm{mt}}+\varepsilon_{\mathrm{it}}
$$

BIST 100 index is used as a proxy of the market returns. Abnormal returns and cumulative abnormal returns are calculated according to the event window $(-3 ;+2)$ and estimation window $(-63 ;-4)$. In other words event window begins 3 days before the announcement day and finishes 2 days after the announcement day. And abnormal returns are 
estimated over the estimation window which begins 4 days before the announcement day and finishes 63 days before the announcement day.

In order the specify event window, we analyzed graphic of pattern for abnormal returns regarding the several event windows and we concluded that stock returns reaction to disclosures are strongest between the 3 days before and 2 days after the announcement day. On the other hand, we used 60 days observation for the estimation window since Lambert and Larcker (1985) and Demirer and Kutan (2010) used same estimation period in their studies.

231 ordinary least squares regression were solved according to the equation 1. Model parameters were statistically significant for 109 announcements. Therefore, our sample is reduced to 109 announcements. Final announcement data is stated in the table 1.

Table I: Transfer announcements displayed on the public disclosure platform

\begin{tabular}{|c|c|c|c|c|}
\hline & Voluntary Disclosure & \multicolumn{2}{|c|}{$\begin{array}{c}\text { Mandatory Disclosure } \\
\text { (Signing of Contract) }\end{array}$} & \\
\cline { 2 - 5 } Football Team & Entering Into Negotiation & (Type 1) & (Type 2) & \multirow{2}{*}{ TOTAL } \\
\hline BJKAS & 16 & 16 & 22 & 54 \\
\hline FENER & 3 & 3 & 1 & 7 \\
\hline GSRAY & 7 & 8 & 17 & 32 \\
\hline TSPOR & 5 & 7 & 4 & 16 \\
\hline Total & $\mathbf{3 1}$ & $\mathbf{3 4}$ & $\mathbf{4 4}$ & $\mathbf{1 0 9}$ \\
\hline
\end{tabular}

Negotiation is a type of announcement which the football teams disclose that they start to negotiations for a transfer. On the other hand, there are two announcement type related to signing a contract which are called Type 1 and Type 2. Type 1 is announcement made when contract is signed following with pre-disclosure of negotiations. Type 2 is announcement made when contract is signed without any pre-disclosure about negotiations. According to the table 1, number of transfer announcements made without any pre-disclosure about negotiations is 44 .

Event Study Metrics, Software copyrighted by ESM UG, was used to perform statistical tests. To check the Event Study Metrics Software, abnormal returns and cumulative abnormal returns are computed manually and compared with the calculations of Event Study Metrics, and no difference was found. 
There are various statistical tests that were developed to conduct the event study analysis. Table 2 states the statistical tests which Event Study Metrics Software can perform. The statistical tests are explained in the appendix A.

\section{Table II: Statistical tests and their assumptions}

\begin{tabular}{|l|l|}
\hline \multicolumn{1}{|c|}{ Statistical Test } & \multicolumn{1}{c|}{ Assumptions } \\
\hline t-Test & $\begin{array}{l}\text { Assumes that 1) the abnormal returns follows a normal distribution 2) Abnormal } \\
\text { returns are cross sectionally uncorrelated }\end{array}$ \\
\hline Patell Z & $\begin{array}{l}\text { The standardized residual test is developed by Patell (1976) since the "assumption } \\
\text { of identically distributed abnormal returns" may be violated. }\end{array}$ \\
\hline Boehmer et al. & According to Boehmer et al. (1991) it is robust test to event induced variance \\
\hline Corrado Rank Test & $\begin{array}{l}\text { The non-parametric test is developed by Corrado (1989). Distributional assumptions } \\
\text { are not necessary for Corrado Rank Test. }\end{array}$ \\
\hline Generalized Sign Test & $\begin{array}{l}\text { Generalized sign test is based on the portion of positive cumulative abnormal } \\
\text { returns over the event window. }\end{array}$ \\
\hline
\end{tabular}

\section{RESULTS}

The pattern of cumulative abnormal returns for both voluntary and mandatory transfer announcements are illustrated in Figure 1. Figure 1 states that stock returns react to all type of transfer announcements. On the other hand, it is clear that largest reaction is observed to the voluntarily announcement of negotiations.

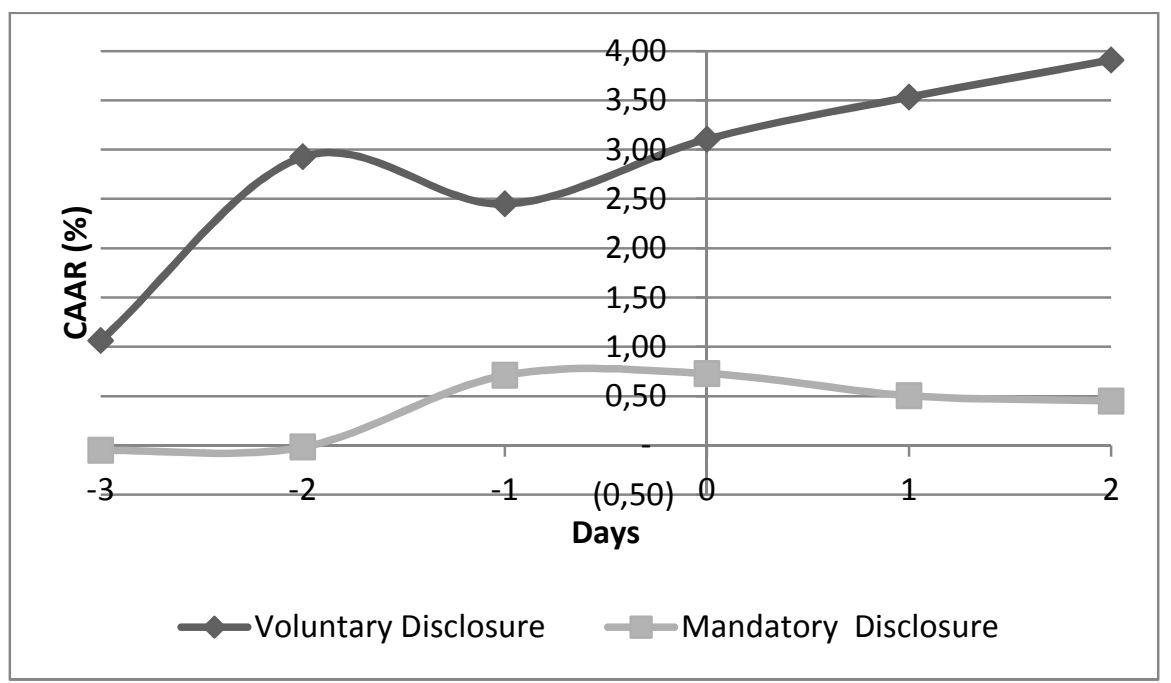

Figure I: Cumulative abnormal returns over the event period for voluntary and mandatory disclosures

Event study Metrics Software performs several parametric and non-parametric tests to answer the question whether the stock returns' reaction to announcements is statistically 
significant or not. Table 3 provides test statistics about voluntary and mandatory disclosures according to the event window $(-3 ;+2)$ and estimation window $(-63 ;-4)$. As it can be seen from this table, the average of cumulative abnormal returns for the voluntary disclosures is $\%$ 3,91 , and average of cumulative abnormal returns for the mandatory disclosures is $\% 0,45$.

Table III: Results of statistical tests

\begin{tabular}{|c|c|c|}
\hline Test Statistics & Voluntary & Mandatory \\
\hline CAAR & 0,0391 & 0,0045 \\
\hline t-Test time-series & $2,3231^{*}$ & 0,4741 \\
\hline Prob. & 0,0202 & 0,6354 \\
\hline t-Test cross-sectional & $2,5894^{*}$ & 0,4008 \\
\hline Prob. & 0,0096 & 0,6886 \\
\hline Patell Z & $3,3405^{*}$ & 0,9471 \\
\hline Prob. & 0,0008 & 0,3436 \\
\hline Boehmer et al. & $2,5368^{*}$ & 0,8756 \\
\hline Prob. & 0,0112 & 0,3812 \\
\hline CorradoRank & $2,0265^{*}$ & 0,5072 \\
\hline Prob. & 0,0427 & 0,612 \\
\hline Sign Test & $2,7493^{*}$ & 0,6879 \\
\hline Prob. & 0,006 & 0,4915 \\
\hline
\end{tabular}

*Significant at 5\%

The data in the Table 3 shows that stock returns' reaction to voluntary disclosures is statistically significant at the level of 5\% according to all parametric and non-parametric tests. However, same results are not valid for the mandatory transfer announcements. Test statistics indicate that cumulative abnormal returns over the event window is statistically close the zero which means that mandatory transfer announcements have no significant effect on stock returns.

Graphical analysis and test statistics support the hypothesis $\mathrm{H}_{1}$ and $\mathrm{H}_{2}$. However, further investigation is needed to understand the behavior of cumulative abnormal returns according to the different announcement types and different event periods.

Figure 2 states that cumulative abnormal returns over the event window have the same tendency for the voluntary and type 2 disclosures while trend is different for the type 1 announcements. Average of cumulative abnormal returns increases during the event period for the voluntary and type 2 disclosures. Regarding to type 1 disclosures, average of cumulative abnormal returns reach to greatest level on announcement date and reach to minimum on the day two. 


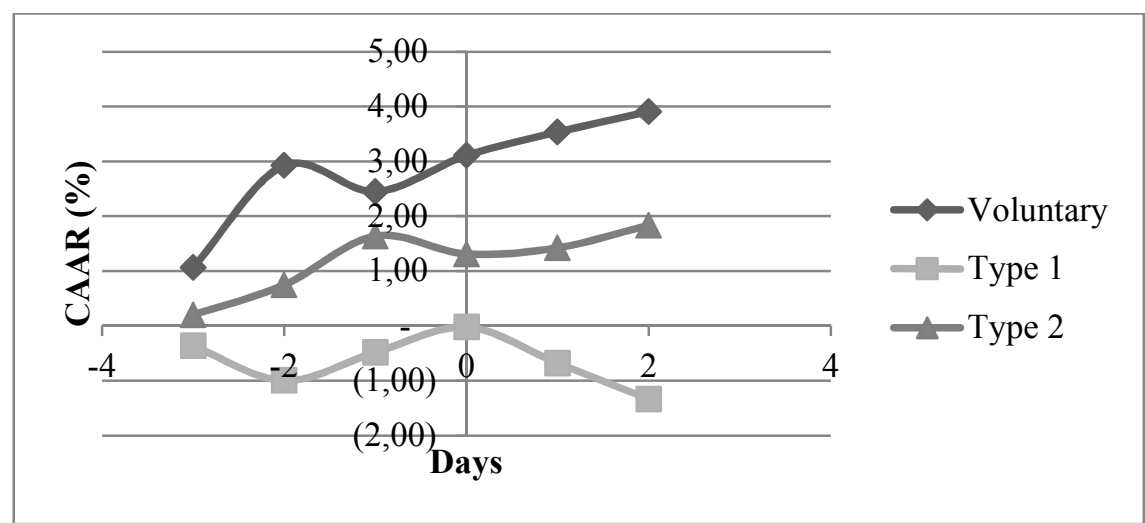

Figure II: Cumulative abnormal returns over the event period for different announcement types

Although type 2 announcements' effect on stock returns seems parallel to the effects of voluntary negotiation disclosures, the effect of type 2 announcements is not statistically significant according to the table 4 .

Table IV: Test statistics according to the type 1 and type 2 announcements

\begin{tabular}{|c|r|r|}
\hline Test Statistics & Type 1 & Type 2 \\
\hline CAAR & $-0,0133$ & 0,0183 \\
\hline t-Test time-series & $-0,8427$ & 1,5718 \\
\hline Prob. & 0,3994 & 0,116 \\
\hline t-Test cross-sectional & $-0,8793$ & 1,1431 \\
\hline Prob. & 0,3793 & 0,253 \\
\hline Patell Z & $-0,3125$ & 1,5358 \\
\hline Prob. & 0,7547 & 0,1246 \\
\hline Boehmer et al. & $-0,331$ & 1,3099 \\
\hline Prob. & 0,7407 & 0,1902 \\
\hline CorradoRank & $-0,7533$ & 1,203 \\
\hline Prob. & 0,4512 & 0,229 \\
\hline Sign Test & $-0,6133$ & 1,4533 \\
\hline Prob. & 0,5397 & 0,1461 \\
\hline
\end{tabular}

Table 5 and Table 6 show the test statistics according to the announcement types for various event windows. Table 5 indicates that stock reactions to the voluntarily announcement of negotiations are statistically significant for the event windows $(-3,3)$ and(2,2) according to the T test, Patell $Z$ test and test suggested by Boehmer et al (1991). 
Table V: Test statistics for announcement of negotiations according to the various event windows

\begin{tabular}{|c|c|c|c|c|c|}
\hline Test Statistics & $(-3 \ldots 3)$ & $(-2 \ldots 3)$ & $(-1 \ldots 3)$ & $(-2 \ldots 2)$ & $(-1 \ldots 2)$ \\
\hline CAAR & 0,0309 & 0,0196 & $-0,0009$ & 0,0282 & 0,0082 \\
\hline t-Test time-series & 1,7007 & 1,1643 & $-0,0603$ & 1,8354 & 0,5943 \\
\hline Prob. & 0,0890 & 0,2443 & 0,9519 & 0,0665 & 0,5523 \\
\hline t-Test cross-sectional & $2,0619^{*}$ & 1,3892 & $-0,0679$ & $2,0269^{*}$ & 0,6551 \\
\hline Prob. & 0,0392 & 0,1648 & 0,9458 & 0,0427 & 0,5124 \\
\hline Patell Z & $2,5767 *$ & 1,8082 & 0,6032 & $2,6229 *$ & 1,4051 \\
\hline Prob. & 0,0100 & 0,0706 & 0,5464 & 0,0087 & 0,1600 \\
\hline Boehmer et al. & $2,0535 *$ & 1,6565 & 0,5150 & $2,2597 *$ & 1,1788 \\
\hline Prob. & 0,0400 & 0,0976 & 0,6065 & 0,0238 & 0,2385 \\
\hline Corrado Rank & 1,4588 & 0,9136 & $-0,0729$ & 1,5371 & 0,5600 \\
\hline Prob. & 0,1446 & 0,3609 & 0,9418 & 0,1243 & 0,5755 \\
\hline Sign Test & 1,6688 & 0,6186 & $-0,4206$ & 1,3392 & 0,6610 \\
\hline Prob. & 0,0952 & 0,5362 & 0,6740 & 0,1805 & 0,5086 \\
\hline
\end{tabular}

*Significant at $5 \%$

Table 6 does not provide parallel results with table 5 for the announcement of signing a contract. According to the table 6 , all tests performed for various event windows state that stock reaction to the mandatory disclosure of signing a contract is not statistically significant.

Table VI: Test statistics for announcement of signing a contract according to the various event windows

\begin{tabular}{|l|l|l|l|l|l|}
\hline Test Statistics & $\mathbf{( - 3 . . . 3 )}$ & $\mathbf{( - 2 . . . 3 )}$ & $\mathbf{( - 1 . . . 3 )}$ & $\mathbf{( - 2 . . . 2 )}$ & $\mathbf{( - 1 . . 2 )}$ \\
\hline CAAR & 0,0139 & 0,0139 & 0,0131 & 0,0046 & 0,0041 \\
\hline t-Test time-series & 1,3457 & 1,4479 & 1,5037 & 0,5296 & 0,5234 \\
\hline Prob. & 0,1784 & 0,1476 & 0,1327 & 0,5964 & 0,6007 \\
\hline t-Test cross- & 1,1290 & 1,1798 & 1,3360 & 0,4419 & 0,4934 \\
\hline Prob. & 0,2589 & 0,2381 & 0,1815 & 0,6585 & 0,6217 \\
\hline Patell Z & 1,8839 & 1,7953 & 1,9280 & 0,8298 & 0,9292 \\
\hline Prob. & 0,0596 & 0,0726 & 0,0539 & 0,4067 & 0,3528 \\
\hline Boehmer et al. & 1,7359 & 1,6603 & 1,8174 & 0,8046 & 0,9456 \\
\hline Prob. & 0,0826 & 0,0969 & 0,0692 & 0,4211 & 0,3444 \\
\hline CorradoRank & 0,9193 & 0,9303 & 1,2573 & 0,4895 & 0,8284 \\
\hline Prob. & 0,3580 & 0,3522 & 0,2086 & 0,6245 & 0,4074 \\
\hline Sign Test & 0,6879 & 1,5796 & 1,3643 & 1,5796 & 1,3643 \\
\hline Prob. & 0,4915 & 0,1142 & 0,1725 & 0,1142 & 0,1725 \\
\hline
\end{tabular}




\section{CONCLUSION}

In this paper, we examined a sample of transfer announcements of football teams to explore how voluntary and mandatory disclosures affect the stock returns. Football teams' transfer announcements provide unique information to compare effects of voluntary and mandatory disclosures.

Our primary finding is that stock returns reaction to "voluntarily announcement of negotiations" and "mandatory announcement of signing a contract" show parallel tendency within the event window. However, reaction of stock returns to the "announcement of negotiations" is statistically significant, while reaction of stock returns to the "announcement of signing a contract" is not significant.

Our examination that is based on the Event Study Methodology supports the hypothesis which states that stock returns react to voluntary disclosures when mandatory disclosures delay the present corporations' facts. For our sample, mandatory disclosures are inadequate since the announcement of signing a contract is delayed. Thus, in Turkey, our hypothesis is valid since mass media distorts communication between the football teams and investors.

The question here is how mass-media distorts the communication? We emphasized the fact that mass media informs the public before football teams. Generally public is informed by mass media on the decision phase about the transfers. That is the logical reason of statistical tests indicate that signing a contract has no impact on the stock returns since investors already knows about the transfer and adjust their beliefs regarding new information before the contract date. Another characteristic of mass media and football teams' relation is false news produced by mass media. False news leads unequal information processing and misevaluation of football teams. To establish perfect communication with the investors, football teams should announce the transfers at the start of negotiations. Thus each investor would receive the true information on exact time. 


\section{APPENDIX A}

\section{A: STATISTICAL TESTS}

The statistical tests which Event Study Metrics Software can run are detailed below. Because there is no uniform notation regarding the statistical tests, we give the variables and formulas as stated in the Event Study Metrics user manual (Andres et al., 2014) and Jong (2007)'s lecture notes.

\section{(1) T Test}

T Statistic is computed according to the equation A.1 and A.2 where CAAR is the cumulated average abnormal returns, $\mathrm{N}$ is the number of disclosures in the sample and $C A R_{i}$ is the cumulated abnormal returns of disclosure $i$.

$$
\begin{gathered}
T=\sqrt{N} \frac{C A A R}{S} \\
s=\sqrt{\frac{1}{N-1} \sum_{i=1}^{N}\left(C A R_{i}-C A A R\right)^{2}}
\end{gathered}
$$

\section{(2) Cross Sectional T test}

Cross sectional $\mathrm{T}$ test is computed as formulated in Equaiton A.3 and A.4 where $C A A R_{t}$ is the Cumulated Averge Abnormal returns on event window $(\mathrm{t}),\left(T_{1}, T_{2}\right)$ denotes the estimation window. The estimation period is indicated by $\mathrm{T}$ which is specified 60 days in this study.

$$
T_{\text {cross }}=\frac{C A A R_{t}}{\bar{s}}
$$




$$
\bar{s}=\sqrt{\frac{1}{T-1} \sum_{t=T_{1}}^{T_{2}}\left(C A R_{i}-C A A R\right)^{2}}
$$

\section{(3) Patell Z Test}

Patell $\mathrm{Z}$ statistic is computed regarding the equations $\mathrm{A} 5$, A6 where $\mathrm{AR}_{\mathrm{i}, \mathrm{t}}$ is the abnormal return of firm $i$ on day $t, S A R$ is the standardized abnormal returns, $S\left(A R_{i}\right)$ is standart deviation of abnormal returns during the estimation period, $M_{i}$ is the number of observations of firm $\mathrm{i}$ in the estimation period, $\mathrm{N}$ is the number of companies, $\mathrm{d}$ is the degree of freedom which is equal to 2 for the market model. $T_{1} \& T_{2}$ denotes estimation period's beginning and ending day.

$$
\begin{gathered}
S A R_{i, t}=\frac{A R_{i, t}}{S\left(A R_{i}\right)} \\
T_{\text {Patell }}=\frac{1}{\sqrt{N}} \sum_{i=1}^{N} \frac{S A R_{i t}}{\sqrt{\left(T_{2}-T_{1}+1\right) \frac{M_{i}-d}{M_{i}-2 d}}}
\end{gathered}
$$

\section{4) Boehmer, Musumeci and Poulson (1991) Test}

Boehmer, Musumeci \& Poulsen (1991) test statistic is computed according to the equations $\mathrm{A} 7$ and $\mathrm{A} 8$ where $A S A R_{t}$ is the average standardized abnormal returns, SAR is the standardized abnormal returns, $\mathrm{S}$ is the estimated cross sectional standard deviation. Finally $\mathrm{t}$ defines the event window and $\mathrm{i}$ defines the each individual disclosure and $\mathrm{N}$ is the number of the disclosures. 


$$
\begin{gathered}
S=\sqrt{\frac{1}{N(N-1)} \sum_{i=1}^{N}\left[S A R_{i t}-A S A R_{t}\right]^{2}} \\
T_{\text {Boehmer et al. }}=\frac{A S A R_{t}}{S / \sqrt{N}}
\end{gathered}
$$

\section{(5) Corrado Rank Test}

ESM runs the Corrado Rank Test according to the equations A.9, A.10, A.11 and A.12 where $K_{i, t}$ is the actual rank of abnormal returns of disclosure i on day t, $L_{1}$ is the number of days in the estimation period and $L_{2}$ is the number of days in the event window, $M_{i}$ is the number of non-missing returns for each asset and $S(U)$ is the estimated standard deviation and $\mathrm{N}$ is the number of disclosures.

$$
\begin{gathered}
K_{i, t}=\operatorname{rank}\left(A R_{i, t}\right) \\
U_{i, T}=\frac{K_{i, T}}{\left(1+M_{i}\right)} \\
T_{\text {corrado }}=\frac{1}{\sqrt{N}} \sum_{i=1}^{N}\left(U_{i ; T}-0,5\right) / S(U) \\
S(U)=\sqrt{\frac{1}{L_{1}+L_{2}} \sum_{T}\left[\frac{1}{\sqrt{N}} \sum_{i=1}^{N_{t}}\left(U_{i ; T}-0,5\right)\right]^{2}}
\end{gathered}
$$




\section{(5) Generalized Sign Test}

ESM runs the Generalized Sign Test according to the equations A.13 where $\mathrm{P}_{0}^{+}$is the observed fraction of positive cumulative abnormal returns and $\mathrm{P}_{\mathrm{est}}^{+}$is the expected fraction possibility.

$$
t_{g s}=\frac{P_{0}^{+}-P_{e s t}^{+}}{\sqrt{P_{e s t}^{+}\left(1-p_{e s t}^{+}\right) / N}}
$$




\section{REFERENCES}

Ajinkya, B.B., \& Gift, M.J. 1984. Corporate managers' earnings forecasts and symmetrical adjustments of market expectations. Journal of Accounting Research, 22(2): 425-444.

Akerlof, G. 1970. The market for lemons: quality uncertainty and the market mechanism. Quarterly Journal of Economics, 84: 488-500.

Andres, C., Betzer, A., Doumet, M., \& Limbach, P. 2014. Event Study Metrics Manual, version 1.05 (Event Study Metrics UG (haftungsbeschränkt)).

Binder, J. 1998. The Event Study Methodology since 1969. Review of Quantitative Finance and Accounting, 11: 111-137.

Boehmer, E., Musumeci, J., \& Poulson, A.B. 1991. Event Study Methodology under conditions of event-induced variance. Journal of Financial Economics, 30(2): 253-272.

Chen, S., Defond, M.L., \& Park, C.W. 2002. Voluntary disclosure of balance sheet information in quarterly earnings announcements. Journal of Accounting and Economics, 33: 229-251.

Corrado, C. 1989. A non parametric test for abnormal security price performance in Event Studies. Journal of Financial Economics, 23(2): 385-395.

Corrado, C. 2011. 'Event Studies: a methodology review, Accounting and Finance. 51: 207234.

Dedman, E., Lin, S.W.J., Prakash, A.J. and Chang C.H. 2008. Voluntary disclosure and its impact on share prices: evidence from the UK biotechnology sector. Journal of Accounting and Public Policy, 27: 195-216.

Demirer, R., \& Kutan, A.M. 2010. The behavior of crude oil spot and futures prices around OPEC and SPR announcements: an event study perspective. Energy Economics, 32:1467-1476.

Diamond, D. \& Verrecchia, R. 1991. Disclosure, liquidity and the cost of capital. The Journal of Finance, 66: 1325-1355.

Graham, J., Harvey, C. R. \& Rajgopal, S. 2005. The economic implications of corporate financial reporting. Journal of Accounting and Economics, 40: 3-73.

Healy, M.P \& Palepu, K.G. 1993. The effects of firms' financial disclosure strategies on stock prices. American Accounting Association Accounting Horizons, 7 (1): 1-11.

Healy, M.P, Hutton, A.P., \& Palepu, K.G. 1999. Stock performance and intermediation changes surrounding sustained increases in disclosure. Contemporary Accounting Research, 16( 3): 485-520.

Jong, F. 2007, Event study methodology, Working paper, Tilburg University. 
KPMG. 2012. Integrated Reporting: Performance Insight Through Better Business Reporting. issue 2, http:// kpmg.com/integratedreporting (Retrieved 10 November 2012).

Kolari, J.W., \& Pynnonen, S. 2011. Nonparatmetric rank tests for Event Studies. Journal of Empirical Finance, 18: 953-971.

Lambert, R.A., \& Larcker, D.F. 1985. Golden parachutes, executive decision- making, and shareholder wealth. Journal of Accounting and Economics, 7: 179-203.

Mackinlay, A.C. 1997. Event Studies in Economics and Finance. Journal of Economic Literature, .35: 13-39.

Özer, G. 1994. Muhasebe karları ile hisse senedi verimleri arasındaki ilişkiler: İMKB'de deneysel bir analiz. Ankara, Sermaye Piyasası Kurulu Yayınları.

Patell, J. 1976. Corporate forecasts of earnings per share and stock price behavior: empirical tests. Journal of Accounting Research, 14(2): 246-276.

Pownall, G., \& Waymire, G. 1989. Voluntary disclosure of credibility and securities prices: evidence from management earnings forecasts, 1969-73. Journal of Accounting Research, 27 (2): 227-245.

Sermaye Piyasası Kurulu (SPK), Özel Durumların Kamuya Açıklanmasına İlişkin Esaslar Tebliği. Seri VIII, No:54, Resmi Gazete, 27133, 06.02,2009.

Strong, N. 1992. Modelling abnormal returns: a review article. Journal of Business Finance \& Accounting, 19(4): 533-553.

Waymire, G. 1984. Additional evidence on the information content of management earnings forecasts. Journal of Accounting Research, 22(2): 703-245. 